\title{
Analysis of Social Economic Condition on Province City Bus (Tomohon-Manado)
}

\author{
${ }^{1}$ Xaverius Erick Lobja* \\ Geography Education Department \\ Universitas Negeri Manado \\ Tondano, Indonesia \\ ericklobja@unima.ac.id
}

\author{
${ }^{2}$ Imanuel Ronald David Mongkau \\ Publishing and Broadcasting \\ Department \\ Politeknik Negeri Media Kreatif \\ Jakarta, Indonesia \\ ronaldmongkau@gmail.com
}

\author{
${ }^{3}$ FonnyRewah \\ Geography Education Department \\ Universitas Negeri Manado \\ Tondano, Indonesia \\ fonnyrewah@unima.ac.id
}

\begin{abstract}
The existence of online transportation and illegal taxi namely "dark taxi" at Tomohon slightly eliminates conventional transportation, especially the Tomohon-Manado city bus route. This condition then contributed to the socio-economic conditions of the Tomohon-Manado public transport bus drivers. The challenge that should be answered by the implementation of conventional public transportation in competition with online transportation and "illegal taxi", is how to survive facing changes and improve their economic conditions. The research is expected to find out the socio-economic condition of the city bus driver at Tomohon - Manado route. This research was designed using a qualitative descriptive approach. This study describes the socioeconomic conditions of Tomohon-Manado public transport bus drivers. The target or object of this study is all Tomohon-Manado bus drivers. The data has been collected is reduced for further analysis to present the data. Furthermore, the data or information are arranged, analyzed deductively, interpreted, and analyzed inductively to conclude the study. The results showed: (1) The entry illegal taxi and online taxis such as Grap, brought significant changes of income from Tomohon-Manado bus drivers, (2) Tomohon-Manado bus driver survived the job due living conditions require them to work and generate income to survive for their family. The number of family dependents is charged to bus drivers for family needs such as clothing, food, housing, and children's education and other needs, (3) Survival strategies undertaken by Tomohon-Manado bus drivers to survive by adding travel trips and try other businesses, like opening a food stall. Some drivers save costs and buy cheap goods.
\end{abstract}

Keywords-Driver, Social, Economy, Income, Bus

\section{INTRODUCTION}

Human mobility and movement from time to time are more intensive and takes place continuously and its volume is increasing. This is due to better transportation facilities. Distances between locations are far away, not an obstacle in modern times. Recently, the movement of people and goods from one place to another is not difficult. One mode of transportation is often used by humans to move or travel from one place to another is the bus. City bus as public transportation is certainly very important in transportation..
As it is known one of the objectives of the presence of public passenger transportation is to provide good and appropriate transportation services for the community. Indicators of good service are safe, comfortable, cheap and fast services. Also, the existence of public transportation has opened employment opportunities. In determining the choice of transportation type, people consider various factors, such as the purpose of the trip, distance and travel time, cost and level of comfort and safety[1]. In the performance of public transportation, there is always a mutually influential relationship between demand and supply. To create a balance, the minimum interests of each should be met, the user arrives at a certain rate, and the service provider does not lose between the request from the passenger and the cost. In terms of traffic, the existence of public passenger transportation means a reduction in the volume of private traffic. This is possible due to public passenger transportation is flexible, can be reached by all groups, but also public transportation is mass transportation costs can be charged to many people means passenger costs can be reduced as low as possible.

The presence of online-based land transportation has also heated public transportation service competition. The emergence of online transportation modes is considered as unfair competition. Unfair competition is simply control of the market and distribution of goods and services. The progress of information technology is a necessity for all fields of business and commerce. There is no single trading business untouched and does not take advantage of information technology. The reason for the use of technology is the efficiency with the interconnection of information technology advancements. The trading community was shocked information technology did not have to be formally incorporated. Online business in various fields including online transportation does not require a corporate form, online transportation business arrangements only require the application of information technology and the application owner does not need to enter the transportation business but only facilitates or simply facilitates it. Since the advent of online transportation, conventional drivers have 
felt competitive. Their income has decreased due to the presence of public transportation cars with this online application. Apart from the competition, currently, both online and conventional transportation services are needed in the mode of transportation, especially land transportation.

In Indonesia generally, at Tomohon in particular, there are several types of conventional transportation such as buses, taxis, public transportation, and motorcycle taxis. So far, conventional transportation is not all good and convenient for passengers or users of conventional transportation services.

As we have seen public transportation creates congestion and vehicles do not make passengers comfortable, the large number of crimes occurred in conventional transportation also reduces people's interest in using conventional transportation. It seems for some users, conventional transportation is still lacking in terms of meeting user convenience, so they prefer to use private vehicles or to use online transportation. Online transportation, which is not much different from conventional transportation, but is considered more convenient and affordable prices.

The existence of online transportation and "dark taxi" in Tomohon slightly eliminates conventional transportation, especially the Tomohon-Manado city bus route. This condition then contributed to the socioeconomic conditions of Tomohon-Manado public transport bus drivers. That is nothing eternal in the world except changes which a necessity. The adage is nothing in the world is eternal except change itself. The arrangement in social life is always changing according to the dynamics occurred in the community itself. Problems should be answered by the implementation of conventional public transportation in competition with traditional transport.

According to Warpani transportation means moving people or goods from one place to another. The goal is to help people or groups of people reach various places they want or send goods from where they came from. The process can be done using transportation facilities in the form of vehicles or without vehicles (transported by people). Public Transportation is passenger transportation conducted with a rental or pay system. Included in the definition of passenger public transportation are city transportation (bus, minibus, etc.), train, water transportation and air transportation [2]

Therefore, the purpose of the public passenger transportation is to provide good and appropriate transportation services for the community. A good measure of service is a safe, comfortable, cheap and fast service. Also, the existence of public transportation has opened employment opportunities. To determine, the choice of transportation type, people consider various factors, such as the purpose of the trip, distance and travel time, cost and level of comfort and safety [1].
Transportation is a geographical element because it can be studied in terms of spatial variables and also determine the boundaries and characteristics of an area. With transportation, space relations between regions can also be analyzed, for example, how the relationship between cities and their hinterland, producer, and their consumer areas, rural areas with their suburbs, cities, and villages, and so on. Limited quality and quantity, if there is no transportation.

The socio-economic life Tomohon-Manado public bus driver is related to the level of income of the drivers, the pattern of the relationship between bus drivers and fellow bus drivers, and passengers. The social life of a bus driver is inseparable from the changes in social behavior that occur in society. Where in the context of social behavior discusses changes in behavior, respect for time, changes in geographical mobility, changes relating to security and changes in emotional behavior.

Suroto [3] explains income is all receipts in the form of money or in the form of goods originating from other parties as well as industrial products which are valued based on the amount of money from assets in effect at the time. Income is a source of income for someone to meet daily needs, which is very important for the survival and livelihood of someone directly or indirectly. Income consists of wages, salaries, rent, dividends, profits and a flow that is measured in a certain period, for example, a week, a month, a year or a long period. The revenue stream arises as a result of the existence of productive services (productive service) that flow in the opposite direction to the income stream ie productive flow from the community to the business which means income should be obtained from productive activities. The expected results in this study are to provide information about the socio-economic conditions of urban transport bus drivers in Tomohon - Manado route province. The virtue of this study is how to reveal the socioeconomic conditions of urban transport bus drivers in Tomohon - Manado province route.

\section{RESEARCH METHODS}

This research was designed using a qualitative approach. The method used is the case study method which is an in-depth exploration of information [4]. This study comprehensively describes the socio-economic conditions of Tomohon-Manado public transport drivers. The target or object of this study is all Tomohon-Manado public transport bus drivers. The selection of informants purposively consisted of Tomohon-Manado bus drivers. Data collection techniques in this study were done by participant observation, observing and listening, capturing the state of social context, capturing events, determining reality, identifying regularities and symptoms in social life, documentation, field notes (researchers as research instruments), and in-depth interviews/non-structural. The data has been collected is reduced for further analysis to present the data. 
Presentation of the data used is a descriptive form and in the form of cases will be verified, analyzed inductively to find regularity, patterns, explanations, causal flow and propositions, information or data obtained can make direct interpretations. Furthermore, the data or information are arranged, analyzed deductively, interpreted to conclude the study.

\section{RESULT AND DISCUSSION}

Based on the results of the study, it can be explained since the entry of online taxis and "dark taxi" the process of transporting passengers from Tomohon to Manado, has varied. But it certainly has an impact on bus drivers. On the other side, it is felt by the public that used online taxis and "dark taxi" is more efficient, because it only waits at the place of order, as well as illegal taxis fill only 7 people at a time, when compared to buses. While on the other hand conventional buses and taxis feel that their profits are lower.

Based on the results of the study, it is known that the average Tomohon-Manado bus driver has worked between 5-25 years and on average they have been conducting transport cars for 7-20 years. The average education level of the Tomohon-Manado bus drivers is dominated by those who have graduated from high school.

Based on the information from several informants, on average, from a total of around 15 bus drivers, Tomohon - Manado completed high school. Furthermore, from the aspect of income received by Tomohon Manado bus drivers, they also experienced a change, namely if previously the entry of online transportation and illegal taxi, the income obtained Rp 1.2 million. However, since online transportation came in and the emergence of illegal taxis served Tomohon-Manado route, in a day a bus driver was only able to earn Rp. 600,000. The average number of dependents based on field research results can be seen on Tomohon - Manado Route bus drivers have some dependents between 2-3 people. Bus drivers also experienced a decrease in the ability to buy clothes.

Meanwhile, the food needs (meals) of each informant are different. Based on information obtained from the informants, their kitchen shopping averaged Rp. 200,000 - Rp. 250,000, this shopping money for daily needs to buy rice, cooking oil, gas or stove oil, fish, chicken, chilies, onions, vegetables, fruits, and so on. There are informants whose spending money can reach Rp 700,000 because the informant has many dependents.

Besides, the need for a place to stay for TomohonManado bus drivers is very important and vital as well as being a basic necessity. Based on the results of the study, it shows the average residence of Tomohon-Manado bus drivers is already their own, even though the house is derived from parents. However, there are bus drivers who are still renting or contracting. The information obtained by the type of house building from the average bus driver is permanent whether renting, contracting or who already have a private home. Based on the conditions, it is clearly illustrated the needs of Tomohon-Manado bus driver boards are good enough according to the standards of a comfortable home. Aside from houses, water sources, electricity, the average bus driver has.

A survival strategy is an action taken by everyone to be able to maintain their survival through the work they do. The survival or adaptation strategy is a process of change conducted by Tomohon-Manado bus drivers with a changing environmental situation. Structural adaptation is a change in the application of action, the habits of bus drivers in responding to environmental changes to maintain their lives, while adaptation strategies are how bus drivers maintain their lives by continuing to exist as bus drivers. In this case, the Tomohon-Manado bus driver is a part of the community that has experienced some changes in the community that have an impact on the existence and income of bus drivers every day. Therefore, Tomohon-Manado bus drivers have several strategies or ways to deal with and maintain the existence of the bus amid the community.

The active strategies undertaken by the TomohonManado bus driver are: (1) Adding a round trip. This is done by the Tomohon-Manado bus driver to supplement the family income. Another way is to look for passengers on the roadside. Besides opening a business or doing other activities such as selling food by opening a food stall.

Besides, the passive strategy undertaken by Tomohon-Manado bus drivers is to save money on expenses incurred by bus drivers in addition to reducing excessive expenses exclude the family's basic needs, besides, the drivers also make savings by keeping caring for the vehicle to remain good, so as much as possible to minimize bus repair costs. Besides, some bus drivers also conduct long-term savings activities as a guide and preparation for the upcoming difficult times or sudden needs.

Based on the conditions experienced by the bus drivers, it can be explained this is in line with the opinion of Rizky [5] which states, in general, a survival strategy (coping strategies) can be defined as a person's ability to implement a set of ways to overcome various problems surrounding his life. This strategy to handle a challenge is the ability of all family members to manage all of their assets.

Besides, it was also emphasized by Edi Suharto [6] who stated the definition of a survival strategy is one's ability to apply a set of ways to overcome various problems that complement his life. He also stated the survival strategy in dealing with shocks and economic pressures can be done in various ways. These methods are grouped into three categories, including a. An active strategy is a strategy that optimizes all the potential of the family. b. a passive strategy is to reduce family expenses. 
c. network strategy is to guarantee relations both formal and informal and the institutional environment.

The strategy conducted by Tomohon-Manado bus drivers, if related to James Scott's Patron-Client Theory [7] which explains the Patron-Client relationship is the exchange of relations between two roles which can be expressed as a special case of a bond involving instrumental friendship where an individual with a higher socioeconomic status (patron) uses his influence and resources to provide protection, as well as benefits for someone with a more stringent social status (client). The client then responds by offering general support and assistance including personal services to his patron. Some of the patterns of exchange, services, and goods exchanged by patrons and clients reflect the needs arise and the resources owned by each party.

\section{CONCLUSION}

Based on the research results, it can be concluded several things as follows:

1. Since the operation of "dark taxi" transportation / illegal taxis and online taxis such as grape, bring significant changes to the income of TomohonManado bus drivers..

2. Tomohon-Manado bus drivers stay with the job due to the living conditions require them to work and can generate income for the survival of their family. Many family responsibilities are borne by bus drivers for family needs such as clothing, food, housing, and children's education and other needs.

3. The survival strategy undertaken by TomohonManado bus drivers is by adding travel trips and trying other businesses, such as opening a food stall. Some drivers save costs and buy cheap goods.

\section{ACKNOWLEDGMENT}

Thank you for Dean Faculty of Social Sciences for supporting this research.

\section{REFERENCES}

[1] Tamin, "Perencanaan dan Permodelan Transportasi," Erlangga, 2000.

[2] S. Warpani, Rekayasa Lalu Lintas. 1993.

[3] Suroto, "Pengertian Pendapatan," Fauzi. 2000.

[4] D. M. A. Lexy J. Moleong, "Metodologi Penelitian Kualitatif (Edisi Revisi)," PT. Remaja Rosda Karya, 2019, doi: 10.1016/j.carbpol.2013.02.055.

[5] E. Rizky, Zulharman, and D. Risma, "Hubungan Efikasi Diri dengan Coping Stress pada Mahasiswa Angkatan 2012 Fakultas Kedokteran Universitas Riau," J. Online Mhs. Fak. Kedokt., vol. 1, no. 1, pp. 1-8, 2014.

[6] D. D. Putra and I. Lelawati, "Study of modeling energy village, a solution for energy independence problem in Indonesia," in Energy Procedia, 2014, doi: 10.1016/j.egypro.2014.01.199.

[7] Kausar dan Komar Zaman, K. Z. Kausar, Elinur, D. S. Priyarsono, M. Tambunan, and M. Firdaus, "Analisis Hubungan Patron-Klien (Studi Kasus Hubungan Toke Dan Petani Sawit Pola Swadaya Di Kecamatan Tambusai Utara Kabupaten Rokan Hulu)," Indones. J. Agric., vol. 2, no. 2, pp. 97 119, 2010. 